Article

\title{
Factors and Strategies for Improving Construction Management on Sites in Mega-Projects in South Africa: An Explorative Survey
}

\author{
Ayodeji Olatunji Aiyetan ${ }^{1}$ and Dillip Kumar Das ${ }^{2, *}$ \\ 1 Department of Construction Management and Quantity Surveying, Durban University of Technology, \\ Durban 4001, South Africa; AyodejiA@dut.ac.za \\ 2 Civil Engineering, Sustainable Transport Research Group (STRg), School of Engineering, Howard College, \\ University of KwaZulu-Natal, Durban 4041, South Africa \\ * Correspondence: dasd@ukzn.ac.za
}

check for updates

Citation: Aiyetan, A.O.; Das, D.K. Factors and Strategies for Improving Construction Management on Sites in Mega-Projects in South Africa: An Explorative Survey. Infrastructures 2022, 7, 19. https://doi.org/10.3390/ infrastructures7020019

Received: 27 December 2021

Accepted: 21 January 2022

Published: 29 January 2022

Publisher's Note: MDPI stays neutral with regard to jurisdictional claims in published maps and institutional affiliations.

Copyright: (C) 2022 by the authors. Licensee MDPI, Basel, Switzerland. This article is an open access article distributed under the terms and conditions of the Creative Commons Attribution (CC BY) license (https:// creativecommons.org/licenses/by/ $4.0 /)$.

\begin{abstract}
Mega-projects, particularly for the development of infrastructure, are being undertaken increasingly in many developing countries. Mega-projects are highly complex and involve significant construction activities. However, mega-projects in Africa face critical challenges of delay and cost overruns because of their nature and the complexities involved. Therefore, using the context of mega-projects in South Africa and stakeholders' perceptions, the factors that influence construction, and strategies that would alleviate the challenges and improve construction management at sites were examined in this study. Factor analysis and ordinal regression modelling were used to analyse data obtained from a survey conducted among stakeholders. Findings suggested that five principal components and associated factors, including stakeholders, plant and machinery, productivity, workforce and materials, significantly affect construction during mega-projects. Further, eight strategies that are aligned to stakeholder engagement, plants and machinery, productivity, human resources and materials are likely to improve construction management at sites of mega-projects in South Africa. The four most important strategies include making the availability of competent personnel for plant and machinery operation and maintenance, effective supervision and monitoring, the adoption of appropriate stakeholder engagement methods and ensuring transparent and effective engagement, and the implementation of an advanced and effective communication system. Further strategies, such as the identification of stakeholders and common goals and procurement and use of advanced and quality plant and machinery, including the use of robotics and automation, could improve construction at sites. Similarly, strategies such as ensuring availability of adequate and quality material, and management of the site for effective accessibility and operation, although likely to have lesser influence, could also improve construction at sites of mega-projects.
\end{abstract}

Keywords: challenges and strategies; construction; construction sites; infrastructure; mega-projects

\section{Introduction}

Nations around the world are focusing on achieving sustainable development; in other words, efforts are being made to achieve economic growth and enhance social benefits without compromising ecology and the environment. Mega-projects are considered to be one of the important strategies for attaining socio-economic development. Specifically, this option is being adopted increasingly in many developing countries, including South Africa [1-3]. Moreover, the sustainable development or socio-economic goals are accomplished by various social and economic development projects which include industrial, transportation, power, water, communication, educational, cultural, medical, and residential projects [4-8]. At the national or regional levels, the scale of these projects ranges from large to mega-projects, which require complex, large-scale or mega-scale construction activities. 
Mega-construction projects are essentially complex, risky and time-consuming undertakings. They are often commissioned by governments or large companies and delivered by national and international participants [8,9]. They differ from other types of construction projects in terms of their sheer scale, huge cost (ranging from a few hundred million to a few billion USD), complexity, stakeholder involvement, long planning procedure, etc., [10,11]. Moreover, they carry a high degree of uncertainty and risk [12-14]. Mega-projects require huge financial resources, competent human resources, materials, equipment and time because of their unique nature and characteristics. Moreover, they require high levels of design knowledge and technical skills, and professional managerial capabilities [15-17]. Therefore, because of the sheer scale and complexities involved, arguments have emerged that mega-projects require sophisticated and advanced management processes as well as highly competent project managers, as opposed to traditional management systems and project managers [14]. However, evidence from the literature suggested that the availability of essential knowledge, competence, skills, capabilities, and finance is a significant challenge [8]. Furthermore, there are no specific project and construction management systems available to manage such projects, although several theoretical frameworks have been suggested to address specific aspects of construction, such as cost, time, safety, risk, quality, socio-political issues, etc., [18]. Consequently, mega-projects are generally managed by traditional project managers using traditional management processes.

Together with the various aspects of managing mega-projects, such as initiation, planning, design, execution, control and monitoring, stakeholder engagement and managing various activities on the construction sites (site management) are also critical factors for the success of mega-projects. Construction at sites of mega-projects involves several aspects, for example, procurement, equipment and machinery, material, labour, construction, quality management, stakeholders' engagement and communication, etc., and various factors under these aspects could be interlinked to each other and influence one another as well as the whole construction process and its management. Therefore, it is necessary to consider the management of various aspects related to construction on-site holistically as a system $[18,19]$. However, first, there is a need to explore various site-related factors that influence the construction, which could assist in understanding the challenges and complexity of construction at sites of mega-projects and examine plausible strategic interventions to resolve such challenges.

In the context of South Africa, several mega-projects were undertaken during the last decade and a half. Some of these projects included the Gautrain Project, Kusile and Medupi Power Station Construction Projects, the Mthombo Fuel Refinery, the Transnet Multi-Products Pipeline and the Venetia Diamond Mine. The cost of some of the projects was more than 2 billion USD. More than 50 mega-projects, to the estimated value of ZAR 360 billion (approximately USD 25 billion) under the Strategic Integrated Projects (SIPs) in terms of the Infrastructure Development Act, have been planned to be undertaken in the near future. These projects belong to the strategic infrastructure areas of transportation, energy, water and sanitation, digital, human relocation and human settlements, which require mega-construction on a mega-scale. However, experience suggests that megaprojects are associated with an increased risk of failures. According to an estimate, $65 \%$ of mega-projects in South Africa have experienced a failure or delay in project delivery [20-22]. Construction-related challenges at the sites of mega-projects contribute significantly to these challenges.

However, very limited researches have been conducted in the context of the construction of mega-projects in South Africa, specifically related to the challenges and complexities of construction at sites. There exists a significant knowledge gap relating to what factors under what important components or aspects contribute to construction challenges at sites and what strategies would improve construction management at sites, in the context of mega-projects of South Africa.

Therefore, using the context of mega-construction projects in South Africa, the objectives of this paper are (1) to identify the major construction site management components 
and explore various influential factors under these components which influence construction on sites in mega-projects, and (2) to evaluate various strategic measures that could assist in improving construction management at the sites of mega-projects. The study was premised upon data about the perceptions of various stakeholders and experts engaged in the construction industry and mega-projects in South Africa. A survey research method was used to collect data from relevant stakeholders. Factor Analysis by use of principal component analysis (PCA) and ordinal regression model estimation was conducted to explore the factors under various principal components and to evaluate the strategic measures, respectively. Findings revealed that stakeholders, plant and machinery, productivity, workforce and materials are the principal components that significantly influence construction at sites in mega-projects. Important strategies include making the availability of competent personnel for plant and machinery operation and maintenance; effective supervision and monitoring; use of advanced quality plant and machinery, including the use of robotics and automation; the adoption of appropriate stakeholder engagement methods, and ensuring transparent and effective engagement; and identification of stakeholders and common goals. Implementation of an advanced and effective communication system is likely to contribute to improving construction management at sites of mega-projects in South Africa.

The paper contributes to bridging the gap in the literature by examining the relevant factors leading to construction-related challenges on sites and plausible strategies to improve the construction management at sites of mega-projects in a developing country such as South Africa.

\section{The Study Context}

Significant footprints of mega-construction projects are found in South Africa. As mentioned above, a significant number of mega-projects were undertaken in the recent past, which involved large-scale construction activities. For example, the construction of more than six football stadiums and the up-grading of related infrastructures, such as national highways, airports and hotels, were undertaken in preparation for the FIFA World Cup in 2010. Furthermore, in recent years, four mega-projects, including Modderfontein Mega City in Johannesburg (USD 8 billion), the Square Kilometer Array telescope (USD 2 billion), the Moloto Road project in Thembisile Hani Municipality of Mpumalanga (USD 217 million) and the BRICS cable project passing through Cape Town (USD 1.5 billion) are being undertaken, which involve large-scale construction works [23]. Similarly, more than 50 mega-projects (Figure 1) in different sectors, such as water, energy, transport, housing, digital technology etc., were gazetted by the government of South Africa under Strategic Integrated Projects (SIP) in 2020 [24]. These projects involve considerably complex construction activities. Experience suggests that several construction projects in the past have faced serious challenges that lead to delay and cost escalation. Moreover, construction site-related challenges are a major contributor to these problems. Therefore, this study was conducted in the context of mega-construction projects, drawing on the perceptions of the stakeholders linked to mega-projects in South Africa. 


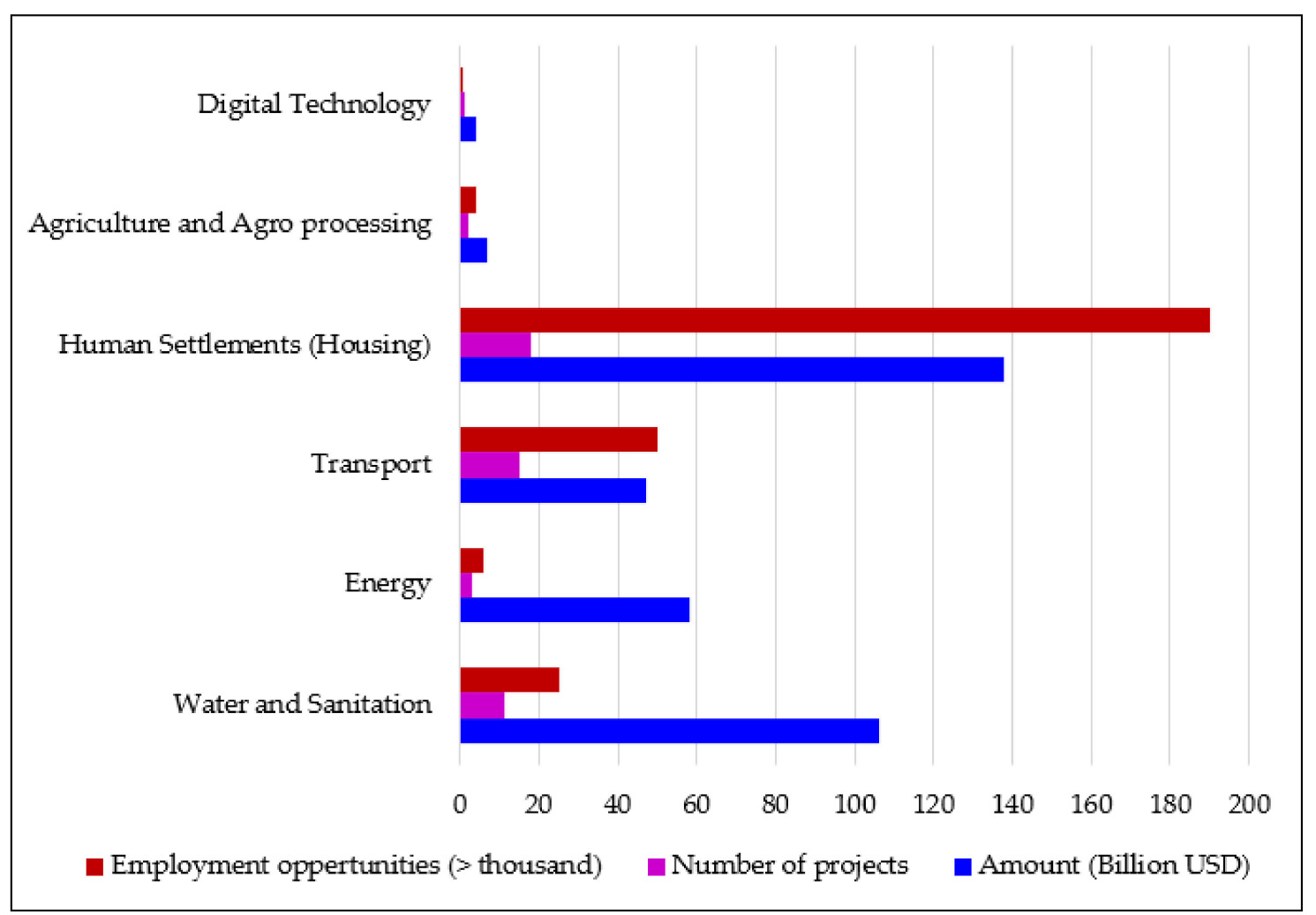

Figure 1. The scenario of future mega-projects to be undertaken per sector in South Africa under SIP [24].

\section{Construction Site Management of Mega-Projects: A Perspective from Literature and Knowledge Gap}

\subsection{Theories for Management of Mega-Projects and the Premise of Systems Theory}

There has been no full-fledged theory developed for mega-projects. However, some of the theories that include the theory of governance, theory and framework of project management, stakeholders theory, institutional theory, systems theory $[18,25,26]$ to name a few have been argued for understanding the complexities and behaviour of mega-projects. However, in the context of this study, as mega-construction projects are complex systems, the premise of systems theory was adopted. According to systems theory, a system is a group of interacting and interrelated elements known as subsystems that work together as a whole to accomplish a goal. It operates in an environment (which is not part of the system) and has components such as boundary, throughput, feedback and control $[18,27]$. The behaviour of the system is dependent on the interaction and influence of the subsystems. Mega-construction projects can be considered as a complex system in which construction is a subsystem. The subsystem of construction at sites of mega-projects could also be considered as a complex system on its own with various elements that include stakeholders engagement, plant and machinery, construction productivity, workforce, materials, health and safety, and socio-political and community contexts [28]. The various aspects of the construction of mega-projects at sites as a complex system are discussed in the following section.

\subsection{Aspects Characterising Construction of Mega-Projects at Sites}

Mega-construction projects are generally characterised by large investment, the complexity of multifarious activities, involvement of a huge number of stakeholders, high risks, and extensive social, economic and environmental impact [29-31]. The need for the augmentation of infrastructure, especially in developing countries, has made mega- 
construction projects increasingly common in recent decades [32-34]. However, since the use of advanced construction and project management strategies and principles has not kept pace with the commissioning of mega-projects, two important challenges, delay and cost overruns, are experienced in mega-construction projects [35]. It has been argued that construction management at the sites of mega-projects is a critical challenge that contributes to the overall success or failure of the mega-projects. Therefore, it was necessary to examine what factors contribute to the challenges with regards to construction on-site, and how construction management can be improved to resolve construction challenges at sites.

Several factors of technical, management and organisational complexity influence mega-construction projects [36]. According to Hu et al. [30], these projects require advanced and sophisticated construction techniques, as well as project and construction management techniques and processes. Furthermore, they also require innovation and ingenious problem-solving [37].

Mega-projects require huge quantities of resources that include human resources, time, money, materials, equipment and machinery. These resources are needed also for a long period of time [26]. Moreover, it has been argued that, since these resources are needed over a long period of time, there is a probability that the requirements of the various stakeholders and customers might change over the life-cycle of the project. This might necessitate additional resources, which must be considered while planning and during the implementation of the project [38].

Although often overlooked, one of the main factors that determine the success of mega-construction projects is the engagement of stakeholders and their inter-dependence. Multiple actors, and specifically the dynamics among the various actors related to construction on sites, play crucial roles in the projects. It has been argued that significant inter-dependencies and interfaces exist between various stakeholders, such as between the project owner, engineers, designers and consultants, diverse contractors, suppliers, community, and so on. According to Damayanti, Hartono and Rahadiyan [39], unsynchronised stakeholders or differences in their goals and motives might lead to conflict, which becomes an obstacle to the success of the construction of mega-projects. Such inter-dependence also requires robust communication systems and strategies [39-41].

It has been argued further that unsynchronised technical circumstances, which include the scope, area, contracts, technology, innovation, labour/experts, etc., influence the construction of mega-projects as well as the activities on sites. For example, the unavailability of competent technical personnel, inadequate competent construction workforce, and equipment and machinery cause challenging conditions for construction on sites. Moreover, geography, spatial location, accessibility of the sites, and the geology of the project sites have a significant impact $[39,42-44]$.

In regards to the impact of the role of plant and machinery, it has been argued that the management of plant and machinery plays a vital role in the success of mega-construction projects, particularly on sites. In recent years, widespread development of mega-civil engineering and construction projects, which require appropriate and advanced plant and machinery, has been witnessed. Moreover, such projects are being deployed increasingly as an economical alternative to costly labour resources [44-46]. The effective utilisation of modern plants and machinery leads to efficient construction, time-saving, quality of work and reduction in cost [47]. Three important aspects are vital in plant and machinery management: plant maintenance, downtime and health and safety, in order to achieve efficient construction on-site [48]. There are other factors also that affect plant management, such as employing expert mechanics in order to increase the quality of the plant and having enough fuel to avoid plant downtime [49]. Furthermore, productivity, optimisation, robotics and automation, machine control, operators and competence have been found also to play major roles in construction [45].

Construction material is also another vital resource, and wastage of material is one of the major challenges on sites. It has been argued that construction materials not only should be available at the site on time, in adequate quantity and appropriate quality, but also 
should be used for the purpose for which they were ordered [50,51]. Any loss of materials or wastage generates direct or indirect costs but does not add any value to the product [52,53]. Therefore, rational management of materials to ensure a supply of adequate and quality material and to avoid waste is an important consideration for reducing construction costs and construction duration in mega-projects. In other words, the overall objective of any on-site construction management activity should be to provide full-guard on construction materials and to perform efficient usage of such materials [54].

Productivity in the construction of mega-projects is the key driver of project success. Poor productivity leads to project failure [55-57]. To manage productivity, it is necessary to understand the factors affecting productivity [55]. There are many reasons for construction firms to emphasise the improvement of productivity when they construct mega-projects. Several factors contribute to poor construction productivity, which includes: the use of inadequate, inappropriate and obsolete construction methods and technology, lack of material, poor design, incomplete drawings, inspection delays, incompetent supervisors, instruction times, lack of tools and equipment, poor communication and poor site conditions [56-59]. Accordingly, it has been argued that such factors should be considered as a priority for the efficient construction of mega-projects on sites.

A competent and adequate workforce is one of the most critical requirements for the construction of any project, let alone mega-projects. The workforce is the lifeblood of any construction project, specifically mega-construction projects [56,60]. In the absence of a workforce, many of the critical tasks that are related to construction, project management, construction management, use of technology, etc., cannot be performed, leading to poor performance of the projects [56,61]. Competent personnel in adequate numbers must be attracted and retained. Moreover, it is essential to build the capacity of personnel by enhancing their skills and their abilities to increase productivity. This is more significant in the case of labour-intensive industries such as construction $[8,56,62]$. This is a major challenge in developing countries, which was evident from the impact of the shortage of a competent workforce for the construction of mega-projects such as the 2010 FIFA World Cup stadiums in South Africa [8,63].

Moreover, several scholars have argued that social and community buy-in is essential for mega-projects, both at the macro and local level, to avoid challenges that might emanate from community protests and unrest $[64,65]$. One of the most important ways to achieve community and society buy-in is through extensive consultation and a participative approach [66]. However, the facilitation of this process requires an appropriate legal framework, the willingness of the project owners and the support of the local governance system [64,67]. Furthermore, according to Brunet (2021) [68], political and governance aspects also impact mega-projects. Specifically, governance frameworks, such as public policy, funding and investment, accountability of the public authorities engaged in mega-projects, conflict among different pressure groups, political rush, political interference and ethical issues are generally found to influence projects $[67,69]$.

Risk management is another important aspect in the construction of mega-projects because of their complex and dynamic nature. According to Chileshe and Haupt [70], management of risk in mega-projects is a continuous and ongoing exercise. The risks generally stem from various activities that include delay, design, construction, site conditions, use of equipment and machinery, materials, workforce, health and safety, etc. Additionally, health and safety aspects include human factors, H\&S legislation, H\&S budget, H\&S induction, training and awareness, site working conditions (for example, lighting and pollution), etc., impact construction at sites [50,59,71-73]. Consequently, the evaluation of risks, especially on sites, and their management in the construction of mega-projects, is of paramount importance to keep the project within schedule and cost $[10,13]$.

Although the challenges of mega-projects are similar in nature to other construction projects, they are more severe and complex because of their size, complexity, duration and dynamic nature. As discussed above, the challenges on construction sites stem from several different aspects and activities that include the availability of resources, their allocation and 
use (in terms of workforce, equipment, materials), engagement of stakeholders and their goals and dynamics, use of advanced technology and innovation, capacity and competence of the workforce, the productivity of construction, amongst others. If not resolved in time, such challenges lead to delay and cost overruns, as evident in examples from various developing countries, including South Africa.

Several studies have been conducted about the challenges and macro and micro strategies and measures that include the use of construction management principles, project management principles, total quality management, risk management at the overall project level and related to construction at the global level. For example, there is evidence in mainstream literature of research studies concerning the factors for success or failure of construction projects, and strategic measures to improve construction and construction management in general or in specific case studies. However, research related to the challenges related to the construction of mega-projects on sites and relevant strategies in developing countries, specifically in South Africa, are scarce [31]. Thus, a knowledge gap was identified, which this study was undertaken to fill.

Premised upon the above facets of construction management at sites of mega-projects, and evidence from literature, a conceptual framework premised upon the systems concept for the aspects and factors that influence construction at sites of mega-projects is presented in Figure 2. However, the details about the aspects and related factors, and sources of evidence (from literature) have been provided in the Appendix A (Table A1).

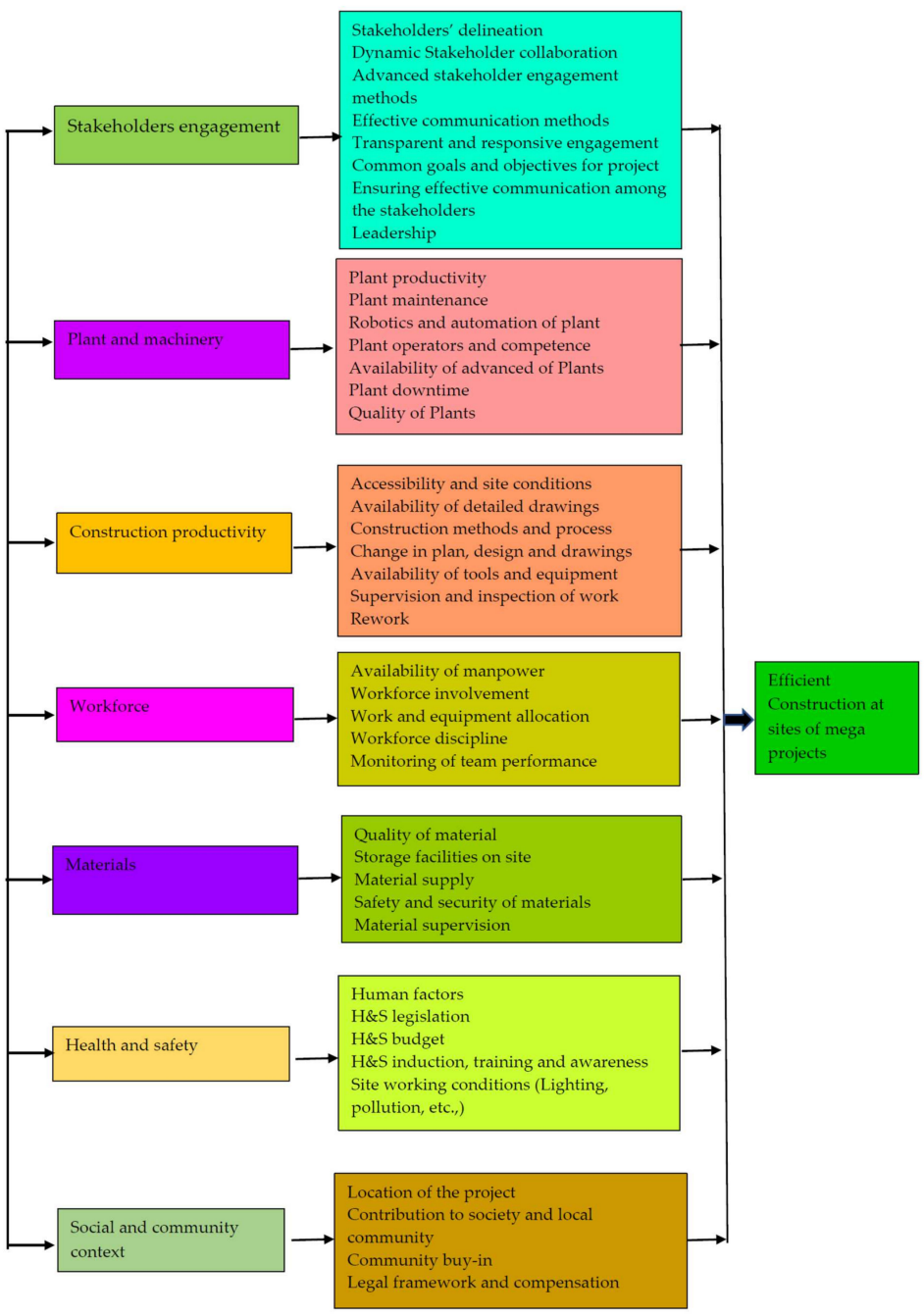

Figure 2. Conceptual framework of challenges and factors influencing the construction of megaprojects on sites. (Note: Compiled from literature sources. Please refer to Table A1 in Appendix A). 


\section{Research Methods}

A survey research method was adopted to collect data and relevant analytical methods, including factor analysis by principal component analysis (PCA) and ordinal regression modelling, were used.

\subsection{Data Collection}

Accessing structured statistical data about factors relevant to constructions sites was a challenge. Therefore, data were collected by conducting a survey among the relevant stakeholders. Perceptions of different stakeholders about the influence of various siterelated factors and plausible strategies on the construction of mega-projects were collected through the survey. For this purpose, the study relied on the perceptions of stakeholders directly or indirectly linked to the construction of mega-projects in South Africa. Apart from the survey among the stakeholders, several other methods that include experts' discussion by using the Delphi method, focus group discussions, the nominal group technique (NGT), and brainstorming, etc., could be used. For example, the Delphi method uses a reasonable number of isolated and anonymous experts to guide group opinions towards a final decision or to answer questions through triangulation of subjective group opinions. It works in a multistage process and is argued to be more accurate than either individual experts, traditional groups or statistical groups in which judgements of non-interacting individuals are aggregated [74]. However, apart from being a slow process and the possibility of a low response rate, it has a challenge of uncertainty in the reliability of the results $[75,76]$. It was also argued that since it is more of a qualitative process, it might not substitute a more evidence-based survey method, which relies on a significant sample size. Similarly, NGT, focus group discussion and brainstorming - although have their advantages-involve only a relatively smaller size of groups in which members might be known to each other and decisions can be taken on voting or consensus [75,77]. Therefore, these methods might not offer more comprehensive results compared to results obtained from data from a survey of stakeholders. Consequently, a survey of stakeholders was conducted instead of using Delphi, NGT, focus group discussion and brainstorming methods.

For the purpose of the survey, relevant stakeholders linked to the construction of mega-projects were identified and a list was compiled. The professional engagement of the stakeholders, their level of education, and their experience were used as the criteria for identifying and listing the stakeholders for the survey. For instance, stakeholders who were directly engaged in the planning, design, management, or decision-making construction of projects on the sites, and had relevant education and significant experience were included as possible respondents. The listed stakeholders were selected randomly from KwaZuluNatal, Gauteng and Western Cape, three provinces of South Africa where most of the mega-projects were located. Before a set of stakeholders were selected as respondents for the survey, the enlisted stakeholders were contacted by email, telephone or personal contact and invited to participate in the survey. Based on the willingness and availability of the stakeholders contacted, the respondents for the survey were selected. Due diligence and care were undertaken not to discriminate on the basis of race, gender, nationality or age and to avoid bias towards a particular section of the stakeholders. A total of 225 stakeholders were contacted, out of which 189 responded, giving a response rate of $84 \%$, which was deemed to be adequate for such an exploratory study.

Table 1 shows the demographic profile of the respondents, which includes the category of respondents, their experience and their engagement with mega-projects. Among the respondents, civil and construction contractors constituted a major share of the respondents, with $22.75 \%$ and $17.46 \%$, respectively. In addition, project managers $(12.70 \%)$, civil engineers $(12.17 \%)$, and site supervisors/administrators $(12.70 \%)$ constituted a significant share of the respondents, followed by quantity surveyors $(7.41 \%)$, plant and equipment operators $(4.23 \%)$, planning engineers $(3.17 \%)$, safety officers $(2.65 \%)$ and others (designers, social facilitators and academics) $(4.23 \%)$ constituted the rest of the respondents. It was found that the professorial engagement of the respondents, in terms of category, varied between $2.65 \%$ 
and $22.75 \%$. This indicated the proportional distribution of the respondents from different categories of stakeholders of mega-projects related to construction on sites. Additionally, it was found that most of the stakeholders (53.97\%) had between 6 and 15 years of experience, whereas more than $42 \%$ of the stakeholders had more than 15 years of experience. This indicated that the respondents had significant experience in mega-projects. Furthermore, approximately $80 \%$ of the respondents had direct or indirect experience related to the construction of mega-projects and, although the other $20 \%$ did not have direct experience of mega-projects, they had experience related to other construction projects. Therefore, it was construed that the sample used for the survey was diverse, relevant and suitable and avoided bias towards any specific category of respondents and skewness in the data.

Table 1. Profile of the respondents.

\begin{tabular}{|c|c|c|}
\hline Respondents & Frequency & $\%$ Share \\
\hline \multicolumn{3}{|l|}{ Professional engagement } \\
\hline Project Managers & 24 & 12.70 \\
\hline Civil Engineers & 23 & 12.17 \\
\hline Planning Engineers & 6 & 3.17 \\
\hline Quantity Surveyors & 14 & 7.41 \\
\hline Safety Officers & 5 & 2.65 \\
\hline Site Agents/Supervisors/Administrators & 24 & 12.70 \\
\hline Plant and Equipment Operators & 9 & 4.76 \\
\hline Construction Contractors & 33 & 17.46 \\
\hline Civil Contractors & 43 & 22.75 \\
\hline Other related professionals (Designers/Academic, Social Facilitators etc.) & 8 & 4.23 \\
\hline \multicolumn{3}{|l|}{ Years of experience } \\
\hline$<5$ years & 6 & 3.17 \\
\hline $6-10$ years & 59 & 31.22 \\
\hline $11-15$ years & 43 & 22.75 \\
\hline$>15$ years & 81 & 42.87 \\
\hline \multicolumn{3}{|l|}{ Participation in mega-projects } \\
\hline Directly participated in mega-projects & 66 & 34.92 \\
\hline Indirect association with mega-projects & 85 & 44.97 \\
\hline Not associated with mega-projects but experience in other construction projects & 38 & 20.11 \\
\hline
\end{tabular}

A pre-tested questionnaire was used for conducting the survey. The questionnaire was prepared to obtain the perceptions of the stakeholders on the influence of various construction site-related factors and plausible strategies that influence construction at sites of mega-projects. The factors and strategies were identified from literature sources (Tables A1 and A2 of Appendix A) and discussions with several stakeholders during the pilot survey stage. The questionnaire included three sections. The first section constituted questions related to the respondents' profiles. The questions included: What is the professional engagement of the respondent? How many years of experience in construction projects including mega-projects the respondent have? What is the type of association of the respondents with mega-construction projects in terms of direct/indirect association or no association at all? The second section constituted questions on the perceptions of respondents on the influence of different factors on construction at sites of mega-projects. These questions were asked at two levels. At the first level, questions were included on whether a factor impacts the construction of mega-projects at the sites. This question was asked on a categorical scale of yes or no. If the answer was yes, then the second level question was asked. The second level questions included what is the level of influence of the factor in a Likert scale of 1 to 5 with 1 indicating very low, 2 indicating low, 3 indicating fair, 4 indicating high and 5 indicating very high. For example, the first level question was: Does delineation of stakeholders' influence construction of mega-projects at sites? The second level question was: What is the influence of delineation of stakeholders on the construction of mega-projects at sites? The third section constituted questions concerning 
the strategies for improving the construction management of sites in mega-projects. The respondents were asked to rate the influence of different strategies for improving the construction of mega-projects at sites. For example, the question that was asked: What is the influence of a strategy of the adoption of appropriate stakeholder engagement methods and ensuring transparent and effective engagement on the improvement of construction in mega-projects at sites (Please rate the influence in the same Likert scale 1-5 mentioned above). The respondents were asked to respond according to their perception premised upon their experience and association with the construction of mega-projects.

Once the draft questionnaire had been prepared, a pilot survey was conducted among 20 stakeholders to check the veracity and relevance of the questions. Based on the feedback, the questionnaire was adjusted and finalised. The questionnaires were administered by emails and personal contacts as appropriate, and responses were collected in the same way.

\subsection{Data Analysis}

The data were analysed and evaluated by using both descriptive and inferential statistical methods including principal component analysis (PCA), and ordinal regression modelling methods. However, before that, descriptive statistical methods were used to analyse the demographic profile of the respondents and the consistency and reliability of the data. PCA was used to carry out factor analysis to identify the major components and linked factors that influence construction at construction sites of mega-projects. The ordinal regression model estimation was carried out to evaluate plausible strategic measures to improve the construction of mega-projects.

Although several other methods, such as generalised linear models (GLM) and multicriteria decision-making models (MCDM) can be used to explore and identify the influential variables in construction projects on sites, PCA was used in this study to carry out dimension reduction and to identify the major components and related factors because it can be used to simplify the complexity of a high dimensional data set without compromising the trends and patterns. Furthermore, PCA can be used to reduce the dimensionality of large data sets and increase the interpretability with minimum information loss and without compromising accuracy $[78,79]$.

While conducting PCA, the five steps that were used included: standardisation of the data; computing the covariance matrix; calculating the eigenvectors and eigenvalues; computing the principal components, and reducing the dimensions of the data set. In this process, Kaiser-Meyer-Olkin measure (KMO) and Bartlett's tests were applied and communalities were computed to verify the adequacy of sample size, validity and robustness of the model. Furthermore, a scree plot was developed to extract and retain the principal components. The components and various linked factors under each component were interpreted by using Varimax rotation.

Ordinal regression model estimation was used to evaluate the relative influence of plausible strategies to improve the construction of mega-projects on sites. Such model estimation is generally done to predict the behaviour of the ordinal dependent variable (the values of which exist on an arbitrary scale) with a set of independent variables [75-77]. Furthermore, such a model estimation can be used to evaluate the influence of various strategies comparatively among each other or to a reference when the data is available on an ordinal scale. For this, the strength of the relationships between two or more variables, the dependence or causal relationship between one or more independent variables, and one dependent variable is assumed [80-82].

For the purpose of model parameter estimation in this study, the log-linked ordinal regression model was used. The mathematical representation of the model is given by Equation (1).

$$
\begin{aligned}
\ln \left(\frac{\gamma_{i}^{(j)}}{1-\gamma_{i}^{(j)}}\right) & =\ln \left(\frac{P\left(Y_{i} \leq j I x_{1}, x_{2}, x_{3}, \ldots \ldots, x_{p}\right)}{1-P\left(Y_{i} \leq j \text { I } x_{1}, x_{2}, x_{3}, \ldots \ldots, x_{p}\right)}\right) \\
& =\tau_{j}-\left(\beta_{1} x_{1}+\beta_{2} x_{2}+\ldots \ldots \ldots \ldots \ldots+\beta_{p} x_{p}\right)
\end{aligned}
$$


where $Y$ is the response variable with $k$ ordered categories

- $j=1,2, \ldots, k-1$;

- $\gamma_{i}^{(j)}$ is cumulative probability $P(Y \leq j)=P(Y=1)+P(Y=2)+\cdots+P(Y=j)$ for $j=1,2$, $\ldots, \mathrm{k}-1$;

- $\quad \gamma_{i}^{(k)}=P(Y \leq k)=1$, so it should not be modelled;

- $Y i$ are dependent observations which are statistically independent $i=1,2, \ldots, \mathrm{n}$;

- $x_{1}, x_{2}, \ldots, x_{p}$ are $p$ explanatory variables;

- $\beta_{1}, \beta_{2}, \beta_{3}$ correspond to the regression coefficients for the respective independent variables;

- $\tau_{j}$ are the cut-off points between categories.

However, before using the model results, the validity and robustness of the model were checked and ensured through the goodness-of-fit, likelihood ratio, Nagelkerke (pseudo R square) and test of parallel lines [83-85].

The IBM-SPSS, V.27 statistical package was used both for analysing the data by PCA and to make an ordinal regression model estimation.

\section{Results}

Two important aspects concerning the construction of mega-projects on sites have been analysed and discussed in the following sections. These aspects include the principal components and related factors that influence construction on sites and the various strategies and measures which could assist in improving construction management at sites.

\subsection{Exploratory Analysis of the Factors That Influence Construction on Sites of Mega-Projects}

An exploratory factor analysis was carried out by using PCA to examine the various attributes and factors that influence the construction of mega-projects on sites. However, before the factor analysis was conducted, the adequacy and validity of the samples were checked by using KMO and Bartlett's test (Table 2). The result of the KMO sample adequacy test was found to be 0.787 . This value was more than the minimum recommended value of 0.6. Similarly, Bartlett's test of sphericity was found to be statistically significant ( $p$-value $=0.000,<0.05)$. These test results indicated that the sample was adequate and the factorability of the correlation matrix was supported.

Table 2. Kaiser-Meyer-Olkin (KMO) and Bartlett's Test results.

\begin{tabular}{lcc}
\hline \multicolumn{2}{c}{ Kaiser-Meyer-Olkin Measure of Sampling Adequacy } & 0.787 \\
\hline \multirow{3}{*}{ Bartlett's Test of Sphericity } & Approx. Chi-Square & 7889.557 \\
\cline { 2 - 3 } & $\mathrm{df}$ & 496 \\
\cline { 2 - 3 } & Sig. & 0.000 \\
\hline
\end{tabular}

Further, the communalities of the factors were found to be more than the minimum recommended value of 0.6 (Table 3). Moreover, the correlation coefficients between various factors were found to range between 0.010 and 0.72 . This implied that the majority of the factors did not have significant correlations, which indicated that the chances of overestimation were marginal. However, two variables were discarded from the PCA analysis as they showed pair-wise strong correlations $(>0.80)$. Based on the above analyses, factor analyses were found to be adequate for this study [68].

The PCA analyses were conducted to extract the principal components which were retained by using a scree plot (Figure 3). Although seven principal components were found to have eigenvalues of more than 1 , the five, most important, principal components were retained (Eigenvalues $>1.75$ ). The total variance of these principal components is shown in Table 4. The predominant components were: Component 1 (18.68\%), Component 2 $(18.47 \%)$, Component $3(16.57 \%)$, Component $4(8.64 \%)$, and Component $5(6.39 \%)$, which resulted in a cumulative variance of $68.78 \%$. 
Table 3. Communalities.

\begin{tabular}{|c|c|c|}
\hline Factors & Initial & Extraction \\
\hline Stakeholders' delineation & 1.000 & 0.910 \\
\hline Dynamic Stakeholder collaboration & 1.000 & 0.919 \\
\hline Advanced stakeholder engagement methods & 1.000 & 0.626 \\
\hline Effective communication methods & 1.000 & 0.780 \\
\hline Transparent and responsive engagement & 1.000 & 0.931 \\
\hline Common goals and objectives for the project & 1.000 & 0.952 \\
\hline Ensuring effective communication among the stakeholders & 1.000 & 0.923 \\
\hline Leadership & 1.000 & 0.628 \\
\hline Plant productivity & 1.000 & 0.866 \\
\hline Plant maintenance & 1.000 & 0.656 \\
\hline Robotics and automation of plant & 1.000 & 0.917 \\
\hline Plant operators and competence & 1.000 & 0.891 \\
\hline Availability of advanced plant & 1.000 & 0.796 \\
\hline Plant downtime & 1.000 & 0.700 \\
\hline Quality of plant & 1.000 & 0.671 \\
\hline Accessibility and site conditions & 1.000 & 0.940 \\
\hline Availability of detailed drawings & 1.000 & 0.871 \\
\hline Construction methods and process & 1.000 & 0.908 \\
\hline Change in plan, design and drawings & 1.000 & 0.685 \\
\hline Availability of tools and equipment & 1.000 & 0.809 \\
\hline Supervision and inspection of work & 1.000 & 0.894 \\
\hline Rework & 1.000 & 0.869 \\
\hline Availability of manpower & 1.000 & 0.685 \\
\hline Workforce involvement & 1.000 & 0.698 \\
\hline Work and equipment allocation & 1.000 & 0.930 \\
\hline Labour discipline & 1.000 & 0.609 \\
\hline Monitoring of team performance & 1.000 & 0.635 \\
\hline Quality of material & 1.000 & 0.730 \\
\hline Storage facilities on site & 1.000 & 0.779 \\
\hline Material supply & 1.000 & 0.790 \\
\hline Safety and security of materials & 1.000 & 0.502 \\
\hline Material supervision & 1.000 & 0.780 \\
\hline \multicolumn{3}{|c|}{ Extraction method: Principal Component Analysis. } \\
\hline
\end{tabular}




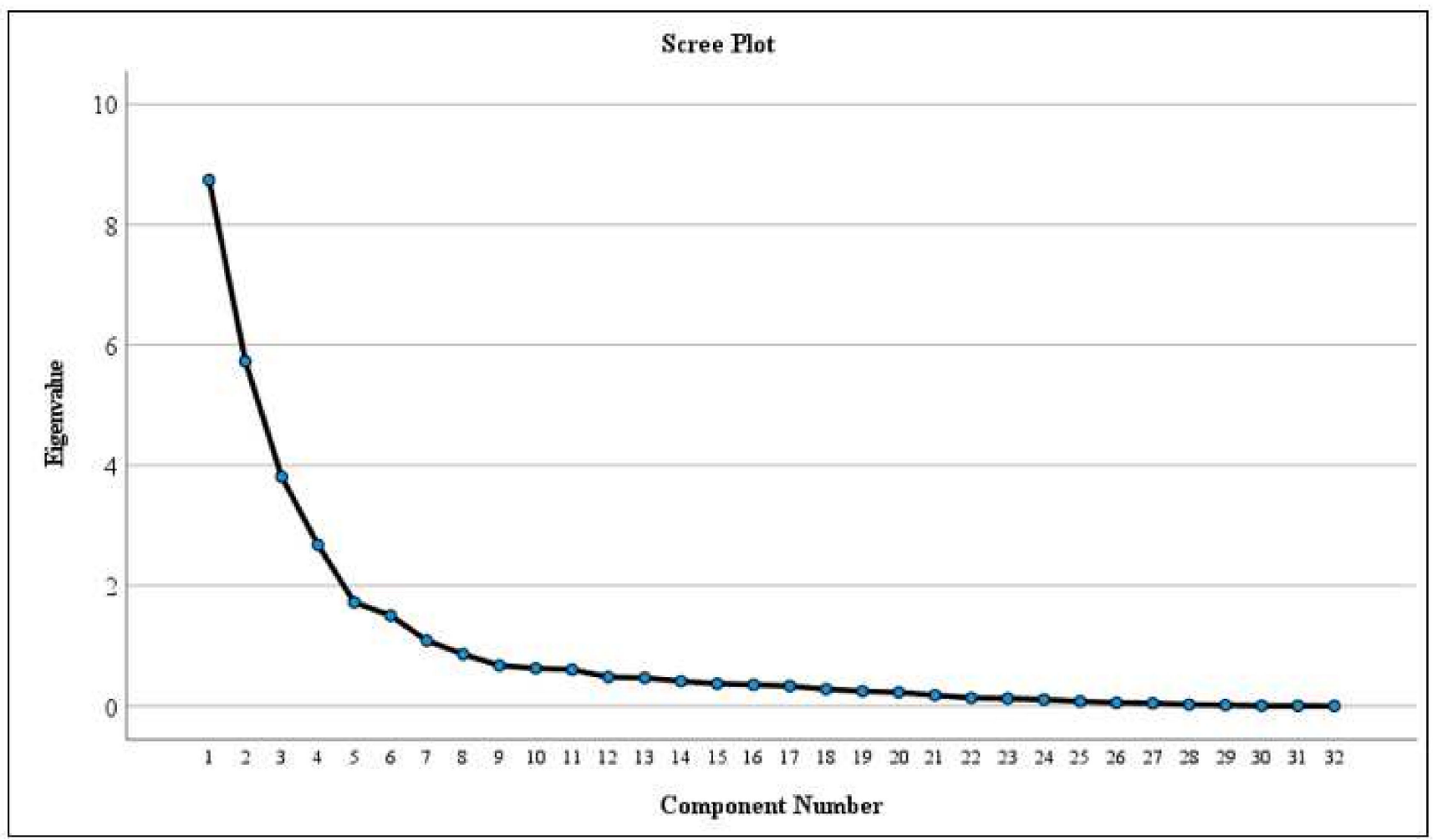

Figure 3. Scree plot used for identifying principal components.

Table 4. Total variance explained.

\begin{tabular}{cccccccccc}
\hline \multirow{2}{*}{ Component } & \multicolumn{3}{c}{ Initial Eigenvalues } & \multicolumn{2}{c}{ Extraction Sums of Squared Loadings } & \multicolumn{2}{c}{ Rotation Sums of Squared Loadings } \\
\cline { 2 - 11 } & Total & $\begin{array}{c}\text { \% of } \\
\text { Variance }\end{array}$ & Cumulative \% & Total & $\begin{array}{c}\text { \% of } \\
\text { Variance }\end{array}$ & Cumulative \% & Total & $\begin{array}{c}\text { \% of } \\
\text { Variance }\end{array}$ & Cumulative \% \\
\hline 1 & 8.743 & 27.321 & 27.321 & 8.743 & 27.321 & 27.321 & 5.978 & 18.683 & 18.683 \\
\hline 2 & 5.729 & 17.904 & 45.225 & 5.729 & 17.904 & 45.225 & 5.912 & 18.476 & 37.159 \\
\hline 3 & 3.811 & 11.910 & 57.134 & 3.811 & 11.910 & 57.134 & 5.304 & 16.576 & 53.735 \\
\hline 4 & 2.679 & 8.373 & 65.508 & 2.679 & 8.373 & 65.508 & 2.767 & 8.647 & 62.382 \\
\hline 5 & 1.725 & 5.390 & 70.898 & 1.725 & 5.390 & 70.898 & 2.047 & 6.397 & 68.779 \\
\hline 6 & 1.505 & 4.703 & 75.600 & 1.505 & 4.703 & 75.600 & 1.655 & 5.173 & 73.952 \\
\hline 7 & 1.088 & 3.400 & 79.000 & 1.088 & 3.400 & 79.000 & 1.615 & 5.048 & 79.000 \\
\hline
\end{tabular}

The various factors under the five components that influence the construction of megaprojects on sites were interpreted by using varimax rotation. Table 5 shows the results of the varimax rotation of the five predominant components. Based on the close alignment of the factors, the principal components were labelled as follows:

1. Stakeholders' engagement;

2. Plant and machinery;

3. Construction productivity;

4. Workforce;

5. Materials.

Each of the principal components and the loaded factors which influence the construction of mega-projects on sites are discussed in the following subsections. 
Table 5. Components and factors and their relative impact on the project delivery (Rotated Component Matrix).

\begin{tabular}{|c|c|c|c|c|c|}
\hline Components/Factors & 1 & 2 & 3 & 4 & 5 \\
\hline Stakeholders' delineation & 0.874 & 0.188 & 0.044 & 0.060 & 0.049 \\
\hline Dynamic Stakeholder collaboration & 0.899 & 0.308 & 0.054 & 0.063 & 0.025 \\
\hline Advanced stakeholder engagement methods & 0.877 & 0.191 & 0.042 & 0.066 & 0.050 \\
\hline Effective communication methods & 0.704 & 0.122 & 0.090 & 0.056 & 0.202 \\
\hline Transparent and responsive engagement & 0.909 & 0.285 & 0.065 & 0.052 & 0.000 \\
\hline Common goals and objectives for project & 0.857 & 0.292 & 0.073 & 0.010 & -0.015 \\
\hline Ensuring effective communication among the stakeholders & 0.884 & 0.163 & 0.066 & 0.049 & 0.011 \\
\hline Leadership & 0.609 & 0.115 & 0.108 & 0.113 & -0.063 \\
\hline Plant productivity & 0.219 & 0.945 & -0.079 & -0.054 & 0.031 \\
\hline Plant maintenance & 0.220 & 0.912 & -0.063 & -0.075 & -0.003 \\
\hline Robotics and automation of plant & 0.189 & 0.867 & -0.094 & 0.006 & 0.102 \\
\hline Plant operators and competence & 0.201 & 0.934 & -0.087 & -0.076 & 0.055 \\
\hline Availability of advanced plant & 0.150 & 0.812 & -0.024 & 0.029 & 0.017 \\
\hline Plant downtime & 0.186 & 0.907 & -0.097 & -0.042 & -0.004 \\
\hline Quality of plant & 0.122 & 0.796 & 0.085 & 0.092 & -0.010 \\
\hline Accessibility and site conditions & 0.119 & -0.072 & 0.933 & 0.032 & -0.073 \\
\hline Availability of detailed drawings & -0.034 & 0.016 & 0.779 & 0.063 & -0.042 \\
\hline Construction methods and process & 0.129 & -0.067 & 0.931 & 0.030 & -0.080 \\
\hline Change in plan, design and drawings & 0.039 & 0.029 & 0.814 & -0.034 & -0.081 \\
\hline Availability of tools and equipment & 0.097 & -0.091 & 0.928 & -0.001 & -0.047 \\
\hline Supervision and inspection of work & -0.036 & 0.001 & 0.818 & 0.034 & 0.014 \\
\hline Re-work & 0.087 & -0.149 & 0.798 & -0.153 & 0.059 \\
\hline Availability of manpower & 0.124 & -0.033 & -0.042 & 0.762 & 0.179 \\
\hline Workforce involvement & 0.044 & -0.035 & 0.035 & 0.798 & 0.252 \\
\hline Work and equipment allocation & -0.008 & -0.015 & 0.069 & 0.849 & -0.216 \\
\hline Labour discipline & 0.102 & -0.007 & -0.055 & 0.625 & 0.082 \\
\hline Monitoring of team performance & 0.306 & -0.006 & -0.036 & 0.063 & 0.159 \\
\hline Quality of material & 0.024 & 0.044 & -0.065 & 0.527 & 0.704 \\
\hline Storage facilities on site & -0.001 & 0.108 & -0.051 & -0.092 & 0.761 \\
\hline Material supply & 0.083 & -0.016 & -0.094 & 0.241 & 0.839 \\
\hline Safety and security of materials & 0.040 & 0.030 & 0.026 & -0.031 & 0.025 \\
\hline Material supervision & -0.036 & 0.017 & 0.138 & -0.034 & -0.033 \\
\hline
\end{tabular}

Extraction Method: Principal component analysis. Rotation Method: Varimax with Kaiser Normalisation ${ }^{a}$ a Rotation converged in 7 iterations.

\subsubsection{Component 1: Stakeholders' Engagement}

The most important principal component was observed to be stakeholders' engagement with an Eigen variance of $27.32 \%$ and Rotation Sums of Squared Loadings of $18.68 \%$. The stakeholders included: the construction workforce (labour), project managers, engineers, contractors, plant and machinery operators, material suppliers, site supervisors or administrators, safety officers, designers, consultants, clients, etc. Seven factors were loaded onto the component. The factors included: stakeholders' delineation (0.874), dynamic stakeholder collaboration (0.899), advanced stakeholder engagement methods (0.877), effective communication methods (0.704), transparent and responsive engagement (0.909), common goals and objectives for a project (0.857), and ensuring effective communication among the stakeholders (0.884). In other words, this component was related to enhancing dynamic collaboration among the stakeholders, understanding the common goals, using advanced effective methods of communication, ensuring effective communication, and resolving conflicts, which essentially play critical roles in taking adequate and timely measures for efficient construction. Thus, this component and the aligned seven factors should be prioritised on the sites of mega-construction projects. 


\subsubsection{Component 2: Plant and Machinery}

With an Eigen variance of $17.90 \%$ and Rotation Sums of Squared Loadings of $18.47 \%$, the second most important principal component that was found to influence construction on sites of mega-projects significantly was related to plant and machinery. Seven factors were loaded onto this component. The factors were: plant productivity (0.945), plant operators and competence (0.934), plant maintenance (0.912), plant downtime (0.907), robotics and automation of plant (0.867), availability of advanced plant (0.812), and quality of plant (0.796). In other words, the availability of advanced and quality plant and machinery, their production capacity, the efficiency of the plant and machinery and competence of the people who operate them, and the maintenance and downtime of the machines impact construction on the sites of mega-projects. Consequently, the challenges related to these aspects should be addressed to improve construction in mega-projects.

\subsubsection{Component 3: Construction Productivity}

Productivity of construction was observed to be the third most significant principal component with an Eigen variance of $11.91 \%$ and Rotation Sums of Squared Loadings of $16.57 \%$. The factors that were loaded onto this component were: accessibility and site conditions (0.933), availability of detailed drawings (0.779), construction methods and process (0.931), change in plan, design and drawings (0.814), availability of equipment and tools (0.928), supervision and inspection of work (0.818), and re-work (0.798). Of these factors, site accessibility and site conditions, construction methods and processes, and availability of equipment and tools had a more significant influence. However, supervision and inspection, change in plan, design and drawings, availability of detailed drawings, and re-work influenced construction productivity to a large extent. Also, this component was interrelated to the first two components of stakeholders' engagement and plant and equipment. Thus, measures should be taken to meet the challenges related to the factors mentioned above under the principal component of construction productivity to achieve efficient construction of mega-projects on sites.

\subsubsection{Component 4: Workforce}

Workforce or construction labour is one of the major components of any construction project. In this study, it was found that workforce was the fourth most significant, principal component with an Eigen variance of $8.37 \%$ and Rotation Sums of Squared Loadings of $8.67 \%$. The four factors were: availability of manpower $(0.762)$, workforce involvement (0.798), work and equipment allocation (0.849), and labour discipline (0.625). Since productivity or efficiency of construction is dependent on the workforce, their availability, engagement or involvement in construction-related activities, allocation or distribution of jobs or activities and equipment to different workforce groups or individuals are of paramount importance. This component had relatively less influence than the first three components. However, since the factors under this component can also influence other components, they should be considered together with the other components and factors.

\subsubsection{Component 5: Materials}

Material is one of the most vital components for any construction. Moreover, the material is more critical for large-scale construction in mega-projects. The analyses revealed that, with an Eigen variance of 5.39\% and Rotation Sums of Squared Loadings of $6.39 \%$, the material is the fifth most significant, principal component of managing construction on sites of mega-projects. However, this was the lowest-ranked, principal component among the five components considered. Three factors: material supply (0.839), quality of material (0.704), and storage facilities on-site (0.761), were loaded onto this component. In other words, the absence of an adequate supply of quality materials would create major challenges in construction. Moreover, if materials were not available in time because of poor or lack of storage facilities at the site, productivity in construction would be likely to suffer. Since construction productivity and engagement of the workforce were related to 
this component, despite its lesser influence, this component and its related factors should be addressed adequately to achieve successful management of construction on the sites of mega-projects.

\subsection{Evaluation of Strategies and Measures for the Management of Construction on Sites of Mega-Projects}

It is necessary to augment the five principal components and related factors mentioned in Section 4.1 to improve the construction management on the sites of mega-projects, which requires appropriate strategies. Therefore, nine strategies (identified as SMID) that have the potential to influence construction management on sites were evaluated in relation to the current scenario. These strategies were framed based on the evidence from literature and perceptions expressed in the stakeholders' discussions and were evaluated by using ordinal regression model estimation (c.f. Section 3.2) to determine their significance and relative influence that could lead to efficient construction management on the sites of mega-projects. However, before the ordinal regression model estimation was carried out, the validity of the model was checked. Table 6 shows the model validation parameters. It was found that the model fit parameter (Likelihood test) had a $p$-value $\leq 0.05(0.000)$, goodness-of-fit value $>0.05$ (0.280) and Nagelkerke (pseudo R square) value $\geq 0.7$, which indicated the validity of the model.

Table 6. Ordinal regression model validation parameters.

\begin{tabular}{ccccc}
\hline Parameter & Chi-Square Value & $p$-Values & Acceptable Values & Validity \\
\hline $\begin{array}{c}\text { Model fitting parameter } \\
\text { (Likelihood test) }\end{array}$ & 346.62 & 0.000 & $\leq 0.05$ & accepted \\
Goodness of fit & 843.18 & 0.280 & $>0.05$ & accepted \\
Nagelkerke (Pseudo R square) & 0.796 & $\geq 0.7$ & accepted \\
\hline
\end{tabular}

Table 7 shows the significance and relative influence (Figure 4) of the strategies evaluated, based on their parameter estimates and significance levels. The strategies have been discussed below.

\begin{tabular}{|l|c|}
\hline SM 5 & 34 \\
\hline SM 6 & 12 \\
\hline SM 1 & 10 \\
\hline SM 2 & 9 \\
\hline SM 3 & 6 \\
\hline SM 4 & 5 \\
\hline SM 9 & 3 \\
\hline SM 7 & 3 \\
\hline
\end{tabular}

Figure 4. The relative influence of different strategic measures on the construction of mega-projects on sites. 
Table 7. Strategic measures for construction site management during mega-projects.

\begin{tabular}{|c|c|c|c|c|c|c|c|c|c|}
\hline SM ID & Strategic Measures (SM) & Related Challenges & $\begin{array}{c}\text { Parameter } \\
\text { Estimate (B) }\end{array}$ & $\operatorname{EXP}(B)$ & Wald & $\begin{array}{l}\text { Upper } \\
\text { Bound }\end{array}$ & $\begin{array}{l}\text { Lower } \\
\text { Bound }\end{array}$ & $p$-Value & Significance \\
\hline 1 & $\begin{array}{l}\text { Adoption of appropriate stakeholder } \\
\text { engagement methods and ensuring } \\
\text { transparent and effective engagement }\end{array}$ & SE, WM & 2.314 & 10.11 & 10.691 & 0.927 & 3.701 & 0.001 & Significant \\
\hline 2 & $\begin{array}{l}\text { Implementation of advanced and } \\
\text { effective communication system }\end{array}$ & SE, WM, PRM & 2.179 & 8.83 & 8.348 & 0.701 & 3.657 & 0.004 & Significant \\
\hline 3 & $\begin{array}{l}\text { Identification of stakeholders and } \\
\text { common goals }\end{array}$ & SE, WM, PRM & 1.717 & 5.57 & 4.926 & 0.20 & 3.23 & 0.026 & Significant \\
\hline 4 & $\begin{array}{l}\text { Procurement and use of advanced and } \\
\text { high-quality plant and machinery } \\
\text { including use of robotics } \\
\text { and automation }\end{array}$ & PMM, PRM & 1.54 & 4.65 & 4.187 & 0.06 & 3.01 & 0.041 & Significant \\
\hline 5 & $\begin{array}{l}\text { Availability of competent personnel for } \\
\text { plant and machinery operation } \\
\text { and maintenance }\end{array}$ & PRM, WM, PMM & 3.535 & 34.30 & 20.89 & 2.02 & 5.05 & 0.000 & Significant \\
\hline 6 & Effective supervision and monitoring & PRM, PMM, WM & 2.497 & 12.13 & 10.56 & 0.99 & 4.00 & 0.001 & Significant \\
\hline 7 & $\begin{array}{l}\text { Management of site for effective } \\
\text { accessibility and operation }\end{array}$ & PRM, PMM, WM, MM & 1.171 & 3.23 & 3.50 & -0.05 & 2.39 & $0.061^{*}$ & Significant \\
\hline 8 & $\begin{array}{l}\text { Quality work and equipment } \\
\text { management }\end{array}$ & WM, PPM, PRM, SE & 0.49 & 1.63 & 0.56 & -0.79 & 1.77 & $0.45^{* *}$ & $\begin{array}{c}\text { Not } \\
\text { significant }\end{array}$ \\
\hline 9 & $\begin{array}{c}\text { Ensuring availability of adequate and } \\
\text { quality material }\end{array}$ & MM, PRM & 1.214 & 3.37 & 2.74 & -0.22 & 2.65 & $0.09 *$ & Significant \\
\hline \multirow[t]{2}{*}{10} & Current systems of construction & & 0 & 1 & & & & & \\
\hline & Cronbach's $\alpha$ & & 0.83 & & & & & & \\
\hline
\end{tabular}

*-Significant at $90 \%$ confidence level and $10 \%$ confidence interval $(p \leq 0.1$ for $\alpha \leq 0.1)$. ${ }^{* *}$ - Not significant.

- SM 1: Adoption of appropriate stakeholder engagement methods and ensuring transparent and effective engagement

Stakeholder engagement was found to be the most essential component for construction management on sites. As observed, although engagement among various stakeholders was undertaken to a certain extent in the current scenario, the use of a consistent, appropriate and scientific method was marginal, which also caused challenges to ensuring effective and transparent engagement. The model results showed that the strategy of adopting appropriate stakeholder engagement methods and ensuring transparent and effective engagement was statistically significant to efficient construction management on sites of mega-projects. Moreover, SM 1 was the third most important strategy that should be adopted $(B=2.314)$. This strategy was also linked to stakeholder engagement $(\mathrm{SE})$, workforce management (WM) and productivity management (PRM). For example, consistent adoption of appropriate methods and transparency would result in all stakeholders having the same information, goals and challenges related to construction on sites. Moreover, all stakeholders would have clarity about their roles and responsibilities and, consequently, the workforce could be managed more effectively to lead to higher construction productivity. Therefore, this strategy would not only facilitate effective stakeholder engagement but also assist in workforce management and construction productivity.

- SM 2: Implementation of an advanced and effective communication system

An advanced and effective communication system is an essential requirement for successful engagement, timely information transfer and collaboration. Although some forms of digital and conventional information systems are used during the construction of mega-projects, it has been argued that consistent and effective use of advanced, digital technology is lacking. The model results showed that this strategy was statistically significant to the construction site management of mega-projects and was the fourth most important strategy to be adopted $(\mathrm{B}=2.179)$. Arguably, this strategy is also linked to stakeholders' engagement (SE), construction productivity (PRM) and workforce management (WM). Consequently, the consistent use of advanced and effective communication systems would assist in improving the activities under these three aspects mentioned above, as well as in resolving or preventing unwarranted challenges. For example, the implementation of an advanced and effective communication system could be one of the important ways to improve stakeholder engagement by bringing all stakeholders together on one platform, sometimes in real-time and without a waste of time. Therefore, it is argued that, if 
such a strategy were implemented, it would improve construction site management in mega-projects significantly.

- $\quad$ SM 3: Identification of stakeholders and common goals

Stakeholders are a vital element of any successful construction project and they are more critical for mega-projects. Since mega-projects have a large number of stakeholders who influence various activities related to construction and could range from clients, contractors, legal entities, engineers, designers and safety personnel to the construction workforce, managing them becomes very difficult. Moreover, the goals of different stakeholders could be different. Therefore, the identification of stakeholders related to construction management, who influence construction significantly on sites is vital. It is also a necessity to ensure that all the relevant stakeholders have common goals. Consequently, from the model results (Table 7), it was found that a strategy linked to the identification of stakeholders and common goals was statistically significant to construction management on sites and was the fifth most important strategy $(B=1.717)$ that should be considered.

- SM 4: Procurement and use of advanced and high-quality plant and machinery, including use of robotics and automation

Plant and machinery were found to be some of the significant principal components which influence the construction of mega-projects. Therefore, it is vital to have adequate and advanced plant and machinery on sites for efficient and fast construction. Moreover, advanced plant and machinery are also linked to an increase in construction productivity, the efficiency of workers and quality of work. Also, in recent times, the use of robotics and automation have been found to play major roles in the increase of efficiency and quality of construction. In this context, the model results showed that a strategy to procure advanced equipment and machinery, as well as the use of robotics and automation, is statistically significant and is the sixth most important strategy $(B=1.54)$ that can assist construction management on the sites of mega-projects. Furthermore, this strategy is linked to plant and machinery management (PMM), construction productivity management (PRM), and workforce management (WM) in enhancing the productivity of construction, and the demand for deployment and efficiency of the workforce are dependent on the availability and use of the type of plant and machinery.

- SM 5: Availability of competent personnel for plant and machinery operation and maintenance

The quality and competence of the workforce are critical to attaining efficiency in construction. In South Africa, the availability of competent personnel, especially in the field of engineering and technology, is a challenge. It has been argued that, even though advanced and high-quality plant and equipment can be procured, in the absence of competent personnel to operate such plant and machinery, it will not benefit construction on sites of mega-projects. Since competent plant and machinery operators or personnel have been found to be scarce in the country, a strategy to recruit, retain, and/or even build competence among the existing personnel is crucial. Moreover, this strategy was linked to construction productivity (PRM), plant and machinery management (PMM) and workforce management (WM), which further increased the importance of this strategy. In this context, from the model results, it was found that this strategy was not only statistically significant to improve construction management on sites of mega-projects but was also the most important strategy $(B=3.535)$ that should be adopted to improve construction in mega-projects.

- $\quad$ SM 6: Effective supervision and monitoring

It has been argued that high-quality and effective supervision and monitoring are critical to improve the productivity of construction, to increase the efficiency of the workforce and to increase the quality of work. In any construction project, supervision and monitoring are integral elements. However, it has been argued also that lack of effective supervision and monitoring is one of the main reasons for the delay in construction, poor 
quality of work and the need for re-work, which essentially are reasons for increased cost and delay. Thus, a strategy for effective supervision and monitoring is needed to improve construction management on sites of mega-projects. The model results revealed that this strategy was statistically significant and was the second most important strategy $(B=2.497)$ that is necessary to improve the construction of mega-projects (Table 7). Furthermore, this strategy was linked to productivity management (PRM), plant and machinery management (PMM) and workforce management (WM). Consequently, this strategy is essential to improving various aspects related to the three aspects of construction on sites of mega-projects mentioned above.

- $\quad$ SM 7: Management of site for effective accessibility and operation

Site management for accessibility and operation of various activities was observed to be an important parameter for successful construction. However, sites of mega-construction projects are usually complex and large, and the accessibility of sites and the operation of various activities, plants and machinery become very challenging. Moreover, site management is essential for the movement and operation of plant and machinery, the movement of materials, and various operations and activities carried out by the workforce. Consequently, site management also has an impact on the productivity of construction. The model results revealed that site management was statistically significant at a $90 \%$ confidence interval ( $p$-value $<0.1$ ) despite being one of the relatively lesser influential strategies $(B=1.171)$ compared with the other strategies needed. However, such a strategy is likely to contribute to improving the construction of mega-projects on sites in combination with the other strategies mentioned above.

- $\quad$ SM8: Quality work and equipment management

Adopting quality management in construction projects has been argued to be one of the important requirements to improve the productivity and quality of construction. However, as shown in Table 7, the evaluation of strategy for quality work and equipment management was found not to be statistically significant to construction management on sites of mega-projects, at both $95 \%$ and $90 \%$ confidence intervals ( $p$-value $>0.1$ ). Thus, whether this strategy will improve the construction of mega-projects on-site could not be ascertained conclusively. This might be because quality management was taken into consideration and was being implemented in mega-projects.

- SM9: Ensuring availability of adequate and high-quality material

Availability of materials and their quality, as observed from the PCA analyses, were found to be essential to improving the productivity of construction on sites. From the model results, it was found that a strategy of ensuring the availability of adequate and high-quality material was statistically significant at a 90\% confidence interval ( $p$-value $<0.1)$. This strategy was linked also to material management (MM) and productivity management (PRM). The model results (Table 7) revealed that the strategy could improve construction on sites of mega-projects although to a lesser extent compared with the other strategies $(\mathrm{B}=1.214)$.

\section{Discussion}

Mega-projects are vital for the socio-economic development of a nation. In recent years, many developing countries have been undertaking large-scale infrastructure development through mega-projects. Mega-projects are complex systems, which essentially involve several construction activities. Because of their complexity, the involvement of a large number of stakeholders and a requirement for sustained human, financial, technological and other resources over a long period of time, significant challenges are experienced, not only in completing the projects but also on construction sites. Different aspects related to mega-projects have been explored in research studies in general, such as project success, complexities, stakeholder engagement, and so on. However, studies about the challenges 
faced in construction on sites and strategies to improve the construction management at sites are scarce, especially in the context of developing countries.

Several mega-projects have been undertaken in South Africa in the past and significant challenges were experienced. For example, both the cost and duration of projects were found to have increased significantly [63]. Furthermore, the country has embarked on undertaking a huge number of projects in the near future involving huge investments [23,24]. Since the majority of the projects involve complex construction activities, constructionrelated challenges on sites are bound to arise. Therefore, it was necessary to examine what challenges occur and how they can be resolved.

In this context, various principal components and related factors that engender significant challenges on construction sites were explored in this study and several strategies that could assist in alleviating the challenges and improving the overall construction management at sites leading to project success were evaluated. In the study, it was found that several factors linked to five principal components influence the construction of megaprojects on sites. In other words, the challenges in construction on sites are engendered largely by these five principal components and associated factors. The five principal components included: stakeholder engagement, plant and machinery, construction productivity, workforce and materials in that ranked order, which were also evident in various mainstream literature in construction management [26,30,39-41,48,56,57].

Regarding stakeholder engagement, enhancement of dynamic collaboration among the stakeholders, understanding the common goals, use of advanced and effective methods of communication, and ensuring effective communication are required to improve construction efficiency on sites $[40,41]$. Plant and machinery were found to be the second most important component that should be considered to enhance the construction of mega-projects on sites. In this context, the availability of advanced and high-quality plant and machinery, the production capacity of the plant and machinery, the competence and efficiency of the operators, and the reduction in downtime were found to be vital $[45,47,48]$. Productivity of construction which was dependent on various aspects, such as productivity of the workforce, plant and machinery and availability of materials and other resources such as design, drawings and so on, was found to be the third most important principal component. Factors, such as the accessibility of sites for movement of plant, machinery, materials and the deployment of the workforce [44,46], design and drawing [86,87], advanced construction methods [30], adequate supervision and competence of supervisors [56,57] should be augmented to improve construction productivity. The workforce was found to be the fourth most important, principal component that influences the construction of mega-projects on sites. Productivity was also dependent on the efficiency and competence of the workforce. Therefore, factors such as the availability of a competent and skilled workforce, appropriate allocation of various activities or jobs and equipment, and successful engagement of the workers in these activities were found to be vital for improving construction on sites of mega-projects $[7,56,60,62,63]$. Furthermore, materials were also observed to be one of the principal components for construction on sites. Linked to this component, the critical factors included the availability of an adequate quantity of materials, their quality and storage facilities. In the absence of these elements, construction on sites is likely to suffer and, therefore, they should be managed adequately, which was evident also from previous studies [51-53,56].

Although the factors and principal components, extracted were observed to have a significant influence on the construction of mega-projects at sites, according to systems theory, premise the interlinkages among various principal components and also the factors are likely to influence the construction and contribute to the complexity [18]. However, examining such interlinkages were not included in the current scope of the study.

However, based on the principal components and the influential factors identified, nine strategies were evaluated for their relative influence on improving construction on the sites of mega-projects. From this study, it was found that the availability of competent personnel for plant and machinery operation and maintenance, effective supervision 
and monitoring, adoption of appropriate stakeholder engagement methods and ensuring transparent and effective engagement, and implementing an advanced and effective communication system were the four foremost strategies which should be adopted. These were followed by strategies, such as the identification of stakeholders and common goals procurement, and the use of advanced and high-quality plant and machinery, including the use of robotics and automation, which are required to improve the construction of megaprojects on sites. In addition, although to a lesser extent, a strategy that includes ensuring the availability of adequate and high-quality material, and management of the site for effective accessibility and operation are expected to contribute to improving construction on the sites of mega-projects. These strategies were linked to the five important construction management challenges of stakeholder management, human resource (workforce) management, productivity management, plant and machinery management and material management, and should be given precedence in the construction at sites of mega-projects.

\section{Conclusions}

Mega-construction projects involve huge investments and significant implications at local and national levels. Experience has shown that often challenges are faced during the construction of mega-projects that lead to both cost and time overruns. It has been argued that challenges related to construction on-site contribute considerably to the over-arching problems faced in mega-projects. Therefore, the various components and factors which significantly influence construction on mega-project sites were examined and various strategies which contribute to alleviating the challenges by improving constriction management at sites were explored in this study.

The findings suggested that five principal components linked to stakeholders, plant and machinery, productivity, workforce and materials and related factors significantly influence the construction of mega-projects at sites. If these components and factors are not addressed adequately, then success, in terms of timely completion without escalation of cost is unlikely to be experienced. Further, it was found in the study that eight strategies, aligned to stakeholder engagement, plant and machinery, productivity, human resources and materials are expected to improve the construction management on sites. Of these eight strategies, the four most important are: the availability of competent personnel for plant and machinery operation and maintenance, effective supervision and monitoring, the adoption of appropriate stakeholder engagement methods and ensuring transparent and effective engagement, and implementing an advanced and effective communication system. Furthermore, it was found that the identification of stakeholders and common goals, and the procurement and use of advanced and quality plant and machinery, including the use of robotics and automation, are useful strategies that could improve construction on sites. Similarly, despite having less influence, strategies such as ensuring availability of adequate and high-quality material, and management of the site for effective accessibility and operation are likely to contribute to the effective construction on the sites of mega-projects.

The study had some limitations. In the absence of structured statistical data, the study was premised on the perception of stakeholders as expressed in a survey. Moreover, only site-related aspects of construction were included in the scope and other economic, socio-political, environmental aspects were not considered. Additionally, although the premise of system theory was adopted in this study, the interlinkage among the various components and factors were kept out of the scope of the study and is considered as the future scope of this research. However, despite the limitations, the findings of the study contribute meaningfully to the field of study by identifying the principal components and related factors that influence the construction of mega-projects on sites, as well as the aligned strategies that could assist in the improvement of construction management of mega-projects on sites in a developing country such as South Africa. 
Author Contributions: The authors have made equal contributions. Conceptualization, A.O.A. and D.K.D.; methodology, D.K.D. and A.O.A.; software, D.K.D.; validation, A.O.A.; formal analysis, D.K.D.; investigation, A.O.A.; resources, A.O.A. and D.K.D.; data curation, A.O.A.; writing-original draft preparation, D.K.D.; writing-review and editing, D.K.D. and A.O.A.; visualization, D.K.D. and A.O.A. All authors have read and agreed to the published version of the manuscript.

Funding: This research received no external funding.

Institutional Review Board Statement: Not applicable.

Informed Consent Statement: Not applicable.

Data Availability Statement: The data will be available on request.

Conflicts of Interest: The authors declare no conflict of interest.

\section{Appendix A}

Table A1. Aspects and related factors with literature sources used in the conceptual framework to improve construction at sites of mega-projects.

\begin{tabular}{|c|c|c|}
\hline Attributes & Factors & Sources \\
\hline Stakeholders engagement & $\begin{array}{c}\text { Delineation of stakeholders and their responsibility } \\
\text { Dynamic collaboration } \\
\text { Engagement methods } \\
\text { Transparent and responsive engagement } \\
\text { Effective communication } \\
\text { Common goals }\end{array}$ & {$[26,30,39,41,66]$} \\
\hline Plant and machinery & $\begin{array}{c}\text { Plant productivity } \\
\text { Plant maintenance } \\
\text { Robotics and automation of plant } \\
\text { Plant operators and competence } \\
\text { Availability of advanced Plants } \\
\text { Plant downtime } \\
\text { Quality of Plants }\end{array}$ & {$[36,43-46,48,55,58]$} \\
\hline Construction productivity & $\begin{array}{l}\text { Accessibility and site conditions } \\
\text { Availability of detailed drawings } \\
\text { Construction methods and process } \\
\text { Change in plan, design and drawings } \\
\text { Availability of tools and equipment } \\
\text { Supervision and inspection of work } \\
\text { Rework }\end{array}$ & {$[30,36,44,55,58,59,88,89]$} \\
\hline Workforce & $\begin{array}{l}\text { Availability of manpower } \\
\text { Workforce involvement } \\
\text { Work and equipment allocation } \\
\text { Workforce discipline } \\
\text { Monitoring of team performance }\end{array}$ & {$[8,36,43,44,56,58,60,61]$} \\
\hline Materials & $\begin{array}{l}\text { Quality of material } \\
\text { Storage facilities on site } \\
\text { Material supply } \\
\text { Safety and security of materials } \\
\text { Material supervision }\end{array}$ & {$[51-56]$} \\
\hline Health and safety & $\begin{array}{c}\text { Human factors } \\
\text { H\&S legislation } \\
\text { H\&S budget } \\
\text { H\&S induction, training and awareness } \\
\text { Site working conditions (Lighting, pollution, etc.,) }\end{array}$ & {$[50,71-73]$} \\
\hline Social and community context & $\begin{array}{c}\text { Location of the project } \\
\text { Contribution to society and local community } \\
\text { Community buy-in } \\
\text { Legal framework and compensation }\end{array}$ & {$[64,66]$} \\
\hline
\end{tabular}


Table A2. Defining strategic measures for improving construction at sites in mega-projects.

\begin{tabular}{|c|c|c|}
\hline SM ID & Strategic Measures (SM) & Sources \\
\hline 1 & $\begin{array}{c}\text { Adoption of appropriate stakeholder engagement methods and } \\
\text { ensuring transparent and effective engagement }\end{array}$ & [39] \\
\hline 2 & Implementation of advanced and effective communication system & [39-41] \\
\hline 3 & Identification of stakeholders and common goals & [90] \\
\hline 4 & $\begin{array}{l}\text { Procurement and use of advanced and high-quality plant and } \\
\text { machinery including use of robotics and automation }\end{array}$ & [44-47] \\
\hline 5 & $\begin{array}{l}\text { Availability of competent personnel for plant and machinery } \\
\text { operation and maintenance }\end{array}$ & {$[49,56]$} \\
\hline 6 & Effective supervision and monitoring & {$[89,91]$} \\
\hline 7 & Management of site for effective accessibility and operation & {$[44,46]$} \\
\hline 8 & Quality work and equipment management & {$[44,46,48]$} \\
\hline 9 & Ensuring availability of adequate and quality material & {$[51-54,56]$} \\
\hline 10 & Current systems of construction & \\
\hline
\end{tabular}

\section{References}

1. Cohen, B. Urbanization in Developing Countries 2006, Current Trends, Future Deloitte on Africa African Construction Trends Report. 2013. Available online: https://www.icafrica.org/fileadmin/documents/Knowledge/Deloitte_Construction_Trends_ Report.pdf (accessed on 14 October 2021).

2. Human Development Report 2011. Available online: http://hdr.undp.org/en/media/HDR_2011_EN_Table1.pdf (accessed on 22 April 2013).

3. Zeybek, H.; Kaynak, M. Role of mega projects in sustainable urban transport in developing countries: The case of Istanbul Marmaray Project. In Proceedings of the Codatu xIII: Sustainable Development Challenges of Transport in Cities of the Developing World: Doing What Works, Ho Chi Minh City, Vietnam, 12-14 November 2008; Available online: http:/ /www.codatu.org/ english/conferences/codatu13/CodatuxIII-CDrom/codCD-Zeybek.pdf (accessed on 3 October 2021).

4. Field, B.; Ofori, G. Construction and economic development-A case study. Third World Plan. Rev. 1988, 10, 41-50. [CrossRef]

5. Khan, R.A. Role of construction sector in economic growth: Empirical evidence from Pakistan economy. In Proceedings of the First International Conference on Construction in Developing Countries (ICCIDC), Karachi, Pakistan, 4-5 August 2008; pp. 279-290.

6. Mthalane, D.; Othman, A.A.E.; Pearl, R.G. The economic and social impacts of Site accidents on the South African society. In Proceedings of the 5th Post Graduate Conference on Construction Industry Development, Bloemfontein, South Africa, 16-18 March 2008; Verster, J.J.P., Marx, H.J., Eds.; Construction Industry Development Board: Pretoria, South Africa, 2008; pp. 1-10.

7. Othman, A.A.E. A study of the causes and effects of contractors' non-compliance with the health and safety regulations in the South African Construction Industry. J. Archit. Eng. Des. Manag. 2012, 8, 180-191. [CrossRef]

8. Othman, A.A.E. Challenges of mega construction projects in developing countries. Organ. Technol. Manag. Constr. Int. J. 2013, 5, 730-746. [CrossRef]

9. Shore, B.; Cross, B.J. Exploring the role of national culture in the management of large-scale international science projects. Int. J. Proj. Manag. 2005, 23, 55-64. [CrossRef]

10. Erol, H.; Dikmen, I.; Atasoy, G.; Birgonul, M.T. Contemporary issues in mega construction projects. In Proceedings of the 5th International Project and Construction Management Conference (IPCMC 2018), Nicosia, Cyprus, 16-18 November 2018; pp. 1022-1035.

11. Flyvbjerg, B. What you should know about megaprojects and why: An overview. Proj. Manag. J. 2014, 45, 6-19. [CrossRef]

12. Boateng, P.; Ahiaga-Dagbui, D.; Chen, Z.; Ogunlana, S. Modelling economic risks in megaproject construction: A systemic approach. In Proceedings of the 31st Association of Researchers in Construction Management (ARCOM) Annual Conference, Lincoln, UK, 7-9 September 2015; pp. 115-124.

13. Kardes, I.; Ozturk, A.; Cavusgil, S.T.; Cavusgil, E. Managing global megaprojects: Complexity and risk management. Int. Bus. Rev. 2013, 22, 905-917. [CrossRef]

14. Priemus, H. Decision-making on mega-projects: Drifting on political discontinuity and market dynamics. EJTIR 2010, 10, 19-29.

15. Sturup, S. Megaprojects and governability. World Acad. Sci. Eng. Technol. 2009, 30, 1031-1040.

16. Frick, K.T. The cost of the technological sublime: Daring ingenuity and the new Sand Francisco-Oakland Bay Bridge. In DecisionMaking on Mega-Projects: Cost-Benefit Analysis, Planning and Innovation; Priemus, H., Flyvbjerg, B., van Wee, B., Eds.; Edward Elgar Publishing Limited: Cheltenham, UK, 2006; pp. 239-262. 
17. Flyvbjerg, B.; Bruzelius, N.; Rothengatter, W. Megaprojects and Risk: An Anatomy of Ambition; Cambridge University Press: Cambridge, UK, 2003.

18. Turk, Ž.; de Soto, B.G.; Mantha, B.R.K.; Maciel, A.; Georgescu, A. A systemic framework for addressing cybersecurity in construction. Autom. Constr. 2022, 133, 103988. [CrossRef]

19. Taylor, R. Systems thinking for project management: Implications for practice and education. Acta Structilia 2010, 17, 79-103.

20. Deloitte. Deloitte on Africa African Construction Trends Report. 2013. Available online: https://www2.deloitte.com/content/ dam/Deloitte/fpc/Documents/secteurs/immobilier/deloitte_etude_african-construction-trends-report-2013.PDF (accessed on 3 October 2021).

21. Khatleli, N. The impediments to efficient megaproject implementation in South Africa. In Proceedings of the 32nd Annual ARCOM Conference, Manchester, UK, 5-7 September 2016; Volume 2, pp. 803-812.

22. Mashegoana, G.; Khatleli, N. Mega construction projects in South Africa: Cultural complexity. In Proceedings of the 11th Annual SACQSP International Conference, Johannesburg, South Africa, 16-17 September 2019.

23. ConstructionReviewOnline. Top Ongoing Mega Projects in South Africa. 2021. Available online: https://constructionreviewonline. com/biggest-projects/top-ongoing-mega-projects-in-south-africa (accessed on 22 April 2021).

24. Businesstech. 50 Major Projects Planned for South Africa-Including a New Mega City and Space Hub. 2020. Available online: https:/ / businesstech.co.za/news/technology/420085/50-major-projects-planned-for-south-africa-including-a-newmega-city-and-space-hub (accessed on 22 April 2021).

25. Awuzie, B.; Ngowi, A. Towards a theory of sustainability in governance of mega-projects: An exploratory study. In Proceedings of the 13th International Conference on Organisation, Technology and Management in construction, Porec, Croatia, 27 September 2017.

26. Biesenthal, C.; Clegg, S.; Mahalingam, A.; Sankaran, S. Applying institutional theories to managing megaprojects. Int. J. Proj. Manag. 2018, 36, 43-54. [CrossRef]

27. Gammack, J.G.; Hobbs, V.; Pigott, D. The Book of Informatics; Cengage Learning: Southbank, Australia, 2007.

28. Matar, M.; Osman, H.; Georgy, M.; Abou-Zeid, A. Sustainable construction modelling: A systems engineering approach. In Proceedings of the Conference Sustainable Construction Modelling: A Systems Engineering Approach, CIB World Building Congress Construction and Society, Brisbane, Australia, 5-9 May 2013; CIB Publication 391. Conseil International du Batiment (CIB) pour la Recherche l'Etude et la Documentation: Rotterdam, The Netherlands, 2013; pp. 383-396. Available online: https://www.irbnet.de/daten/iconda/CIB_DC27459.pdf (accessed on 15 August 2021).

29. Chapman, R.J. A framework for examining the dimensions and characteristics of complexity inherent within rail megaprojects. Int. J. Proj. Manag. 2016, 34, 937-956. [CrossRef]

30. Hu, Y.; Chan, A.P.C.; Le, Y.; Jin, R. From construction megaproject management to complex project management: Bibliographic analysis. J. Manag. Eng. 2015, 31, 04014052. [CrossRef]

31. Pollack, J.; Biesenthal, C.; Sankaran, S.; Clegg, S. Classics in megaproject management: A structured analysis of three major works. Int. J. Proj. Manag. 2018, 36, 372-384. [CrossRef]

32. Jia, G.; Yang, F.; Wang, G.; Hong, B.; You, R. A study of mega-project from a perspective of social conflict theory. Int. J. Proj. Manag. 2011, 29, 817-827. [CrossRef]

33. Ma, H.; Zeng, S.; Lin, H.; Chen, H.; Shi, J.J. The societal governance of megaproject social responsibility. Int. J. Proj. Manag. 2017, 35, 1365-1377. [CrossRef]

34. Van Marrewijk, A. The multivocality of symbols: A longitudinal study of the symbolic dimensions of the high-speed train megaproject (1995-2015). Proj. Manag. J. 2017, 48, 47-59. [CrossRef]

35. Eweje, J.; Turner, R.; Müller, R. Maximizing strategic value from megaprojects: The influence of information-feed on decisionmaking by the project manager. Int. J. Proj. Manag. 2012, 30, 639-651. [CrossRef]

36. Baccarini, D. The concept of project complexity-A review. Int. J. Proj. Manag. 1996, 14, 201-204. [CrossRef]

37. Brockmann, C.; Brezinski, H.; Erbe, A. Innovation in construction megaprojects. J. Constr. Eng. Manag. 2016, $142,04016059$. [CrossRef]

38. Jergeas, G.F.; Ruwanpura, J. Why cost and schedule overruns on mega oil sands projects? Pract. Period. Struct. Des. Constr. 2010, 15, 40-43. [CrossRef]

39. Damayanti, R.W.; Hartono, B.; Rahadiyan, A.W. Clarifying megaproject complexity in developing countries: A literature review and conceptual study. Int. J. Eng. Bus. Manag. 2021, 13, 1-25. [CrossRef]

40. Pitsis, A.; Clegg, S.; Freeder, D.; Sankaran, S.; Burdon, S. Megaprojects redefined-Complexity vs cost and social imperatives. Int. J. Manag. Proj. Bus. 2018, 11, 7-34. [CrossRef]

41. Wu, G.; Zhao, X.; Zuo, J. Effects of inter-organizational conflicts on construction project added value in China. Int. J. Confl. Manag. 2018, 28, 695-723. [CrossRef]

42. London, K.; Siva, J.P.S. The role of reflexive capability in relation to intellectual capital on multi international partnerships. Int. J. Proj. Manag. 2011, 29, 846-855. [CrossRef]

43. Oyegoke, A.S.; Al Kiyumi, N. The causes, impacts and mitigations of delay in megaprojects in the Sultanate of Oman. J. Financ. Manag. Prop. Constr. 2017, 22, 286-302. [CrossRef]

44. Lin, J.J.-C.; Yang, C.-E.; Hung, W.-H.; Kang, S.-C. Accessibility evaluation system for site layout planning-A tractor trailer example. Vis. Eng. 2013, 1, 12. [CrossRef] 
45. Edwards, D.J.; Holt, G.D. Construction plant and equipment management research: Thematic review. J. Eng. Des. Technol. 2009, 7, 186-206. [CrossRef]

46. Su, X.; Andoh, A.R.; Cai, H.; Pan, J.; Kandil, A.; Said, H.M. GIS-based dynamic construction site material layout evaluation for building renovation projects. Autom. Constr. 2012, 27, 40-49. [CrossRef]

47. Hendrickson, C. Project Management for Construction. 2000. Available online: http://www.ce.cmu.edu/ \{\{cth/PMBook/ (accessed on 16 October 2021).

48. Aadal, H.; Rad, K.G.; Fard, A.B.; Sabet, P.G.P.; Morshedi, R. Impact of plant and equipment in construction industry. Maxwell Science Publication. Res. J. Appl. Sci. Eng. Technol. 2014, 7, 2371-2375. [CrossRef]

49. Bahru, J.; Malaysia, T. Major emergency assessor. In University Manual of Occupational Safety and Health; University Teknologi Malaysia: Johor Darul Ta'zim, Malaysia, 2014.

50. Edward, D.J.; Holt, H.G. Construction workers health and safety knowledge: Initial observation on some test-Result data. J. Eng. Des. Technol. 2008, 6, 65-68. [CrossRef]

51. Onabule, P. Waste Dumpers Turning to West Africa. 2014. Available online: https://www.nytimes.com/1988/07/17/world/ waste-dumpers-turning-to-west-africa.html (accessed on 12 September 2021).

52. Arslan, H.; Nilay, C.; Salgin, B. Construction and demolition waste management in Turkey. In Waste Management-An Integrated Vision; Rebellón, L.F.M., Ed.; InTechOpen: London, UK, 2012; Available online: https:/ /www.intechopen.com/chapters/40493 (accessed on 14 October 2021). [CrossRef]

53. Formoso, C.T.; Isatto, E.L.; Hirota, E. Method for Waste Control in the Building Industry. In Proceedings of the IGLC-7: Seventh Conference of the International Group for Lean Construction, Berkeley, CA, USA, 26-28 July 1999.

54. Fathi, M.S.; Anumba, C.J.; Carillo, P. Context awareness in construction management-Key issues \& issues enabling technologies Proceedings of The Joint International Conference on Construction Culture, Innovation and Management (CCIM), Dubai, United Arab Emirates, 26-29 November 2006.

55. Sezer, A.A. Contractor use of productivity and sustainability indicators for building refurbishment. Built Environ. Proj. Asset Manag. 2015, 5, 141-153. [CrossRef]

56. Alaghbari, W.; Al-Sakkaf, A.A.; Sultan, B. Factors affecting construction labour productivity in Yemen. Int. J. Constr. Manag. 2017, 19, 1-13. [CrossRef]

57. Gunduz, M.; Almuajebh, M. Critical Success Factors for Sustainable Construction Project Management. Sustainability 2020, 12, 1990. [CrossRef]

58. Makulsawtudom, A.; Emsley, M.; Sinthawanarong, K. Critical factors influencing construction productivity in Thailand. J. Constr. Dev. Ctries. 2009, 19, 53-63.

59. El-Sabek, L.M.; McCabe, B.Y. Coordination Challenges of Production Planning in the Construction of International Mega-Projects in The Middle East. Int. J. Constr. Educ. Res. 2018, 14, 118-140. [CrossRef]

60. Ramburan, S.; Othman, A.A.E. Improving the skills of physically disable persons for economic and social development in South Africa. In Proceedings of the International Conference on Sustainable Human Settlements for Economic and Social Development, Zambezi Sun International Hotel, Livingstone, Zambia, 2-5 May 2007; pp. 494-512.

61. Georgieva, T.M. Research Infrastructure megaproject (RIMPS) Management in an ecosystem perspective: Literature Review. Organ. Technol. Manag. Constr. Int. J. 2012, 3, 333-347. [CrossRef]

62. Loosemore, M.; Dainty, A.; Lingard, H. Human Resource Management in Construction Projects: Strategic and Operational Approach; Spon Press: Oxford, UK, 2003.

63. Baloyi, L.; Bekker, M. Causes of construction cost and time overruns: The 2010 FIFA World Cup stadia in South Africa. Acta Structilia 2011, 18, 51-67.

64. Kwena, G.N. Factors Affecting Community Participation Management of Development through Local Authority Service Delivery Action Plan: A Case Study of Kilgoris Constituency, Narok Country. Ph.D. Thesis, The Management University of Africa, Nirobi, Kenya, 2013.

65. Phala, D. IDT-Social facilitation and EPWP best practice. In Proceedings of the 4th EPWP Municipal Summit, St Georges Hotel, Gauteng, South Africa, 27-28 November 2014

66. Terry, H.Y.; Thomas, S.; Martin, S. Evaluating stakeholder satisfaction during public participation in major infrastructure and construction projects: A fuzzy approach. Autom. Constr. 2013, 29, 123-135.

67. Bonga, B.M. Partnership As a Strategy in Implementing Sustainable Community Development in Mandeni Municipality. Master's Thesis, University of Zululand, Zululand, South Africa, 2012.

68. Brunet, M. Making sense of a governance framework for megaprojects: The challenge of finding equilibrium. Int. J. Proj. Manag. 2021, 39, 406-416. [CrossRef]

69. Aiyetan, O.A.; Das, D. Evaluation of the Factors and Strategies for Water Infrastructure Project Delivery in South Africa. Infrastructures 2021, 6, 65. [CrossRef]

70. Chileshe, N.; Haupt, T.C. Industry and academia perceptions of construction management education-The case of South Africa. J. Educ. Built Environ. 2007, 2, 85-114. [CrossRef]

71. Nawaz, A.; Su, X.; Mohi Ud Din, Q.; Khalid, M.I.; Bilal, M.; Shah, S.A.R. Identification of the H\&S (Health and Safety Factors) Involved in Infrastructure Projects in Developing Countries-A Sequential Mixed Method Approach of OLMT-Project. Int. J. Environ. Res. Public Health 2020, 17, 635. [CrossRef] 
72. Zhou, X.H.; Shen, S.L.; Xu, Y.S.; Zhou, A.N. Analysis of production safety in the construction industry of China in 2018. Sustainability 2019, 11, 4357. [CrossRef]

73. Zahoor, H.; Chan, A.P.C.; Utama, W.P.; Gao, R. A research framework for investigating the relationship between safety climate and safety performance in the construction of multi-storey buildings in Pakistan. Procedia Eng. 2015, 118, 581-589. [CrossRef]

74. Rowe, G.; Wright, G. Expert opinions in forecasting: The role of the Delphi Technique. In Principles of Forecasting; International Series in Operations Research \& Management Science; Armstrong, J.S., Ed.; Springer: Boston, MA, USA, 2001 ; Volume 30. [CrossRef]

75. Cantrill, J.A.; Sibbald, B.; Buetow, S. The Delphi and nominal group-Techniques in health services research. Int. J. Pharm. Pract. 1996, 4, 67-74. [CrossRef]

76. Fink-Hafner, D.; Dagen, T.; Dousak, M.; Novak, M.; Hafner-Fink, M. Delphi Method: Strengths and Weaknesses. Metodološki Zvezki 2019, 16, 1-19. [CrossRef]

77. Brahm, C.; Kleiner, B.H. Advantages and disadvantages of group decision-making approaches. Team Perform. Manag. 1996, 2 , 30-35. [CrossRef]

78. Jolliffe, I.T.; Cadima, J. Principal component analysis: A review and recent developments. Phil. Trans. R. Soc. A 2016, 374, 20150202. [CrossRef]

79. Velliangiria, S.; Alagumuthukrishnan, S.; Joseph, S.I.T. A Review of the Dimensionality Reduction Techniques for Efficient Computation. Procedia Comput. Sci. 2019, 165, 104-111. [CrossRef]

80. Lu, P.; Wang, H.; Tolliver, D. Prediction of bridge component ratings using Ordinal Logistic Regression Model. Math. Probl. Eng. 2019, 2019, 9797584. [CrossRef]

81. Williams, R.A.; Quiroz, C. Ordinal Regression Models. In SAGE Research Methods Foundations; Atkinson, P., Delamont, S., Cernat, A., Sakshaug, J.W., Williams, R.A., Eds.; SAGE Publication Limited: London, UK, 2020. [CrossRef]

82. Winship, C.; Mare, R.D. Regression Models with Ordinal Variables. Am. Sociol. Rev. 1984, 49, 512-525. [CrossRef]

83. Ananth, C.V.; Kleinbaum, D.G. Regression models for ordinal data: A review of methods and applications. Int. J. Epidemiol. 2016, 26, 1323-1333. [CrossRef] [PubMed]

84. Fagerlanda, M.W.; Hosmer, D.W. A goodness-of-fit test for the proportional odds regression model. Stat. Med. 2015, 32, 2235-2249. [CrossRef] [PubMed]

85. Scott, L.J.; Freese, J. Regression Models for Categorical Dependent Variables Using Stata, 3rd ed.; Stata Press: College Station, TX, USA, 2014

86. Carretero-Ayuso, M.J.; García-Sanz-Calcedo, J.; Rodríguez-Jiménez, C.E. Characterization and Appraisal of Technical Specifications in Brick Façade Projects in Spain. J. Perform. Constr. Facil. 2018, 32, 04018012. [CrossRef]

87. Golabchi, A.; Guo, X.; Liu, M.; Han, S.; Lee, S.; AbouRizk, S. An integrated ergonomics framework for evaluation and design of construction operations. Autom. Constr. 2018, 95, 72-85. [CrossRef]

88. Aiyetan, O.A.; Das, D. Using system dynamics modelling principles to resolve problems of rework in construction projects in Nigeria. J. Constr. Proj. Manag. Innov. 2015, 5, 1266-1295.

89. Dalibi, S.G. Resultant Effects of Poor Supervision in Construction Projects in Nigeria. In Proceedings of the 6th Building and Construction Economic Round Table (BCERT-6), The Quantity Surveyors Registration Board of Nigeria (QSRBN), Abuja, Nigeria, 14-15 July 2016.

90. Eyiah-Botwe, E.; Aigbavboa, C.; Thwala, W.D. Mega Construction Projects: Using stakeholder management for enhanced sustainable construction. Am. J. Eng. Res. AJER 2018, 5, 80-86.

91. Tengan, C.; Aigbavboa, C. The Role of Monitoring and Evaluation in Construction Project Management. In Intelligent Human Systems Integration: Advances in Intelligent Systems and Computing; Karwowski, W., Ahram, T., Eds.; Springer: Cham, Switzerland, 2018; pp. 571-582. [CrossRef] 